\title{
Book Review: Quick Hits for Teaching with Technology: Successful Strategies by Award-Winning Teachers
}

\author{
Stephanie Healy \\ Alumna, Park University \\ School for Education and Department of English
}

Technology: It is a word that inspires and excites many educators. It can also strike fear in the hearts of even the most forward-thinking teachers who embrace technological tools to advance effective teaching practices. Questions about how much technology should be included in any given lesson, or what kind of technology might enhance the learning of students, are valid and extremely important aspects to the use of technology in the regular or virtual classroom. Quick Hits for Teaching with Technology: Successful Strategies by Award-Winning Teachers, edited by Robin K.

The information provided within the essays is diverse and easily adaptable to the...needs of the educator looking for...innovative ways to enhance student learning....

Morgan and Kimberly T. Olivares and published by Indiana University's Faculty Colloquium on Excellence in Teaching (FACET), contains essays describing practical, tried-and-true uses of technology in the classroom. The collection of essays is designed to be a quick guide for educators, assisting them to effectively use the many great tools available (some for a small fee, others at no charge) to promote student engagement in the classroom, provide access to a multitude of learning styles, enhance the evaluation of both student learning and teacher effectiveness, and finally, make teaching and learning more effective.

The collection is organized into sections based on the above-mentioned principles: promoting engagement, providing access, enhancing evaluation, and becoming more efficient. Each section includes selected essays whose authors explain in detail why they chose to use technology, what technology was incorporated, how it was incorporated, what results came from the use of technology, and how to adapt what they used to different types of classrooms as well as different disciplines. My only suggestion for a more user-friendly format would have been to organize the essays according to the discipline each was originally created for. This would have made it easier for the researching educator to find possible technological uses that could be adapted to his or her specific needs.

The information provided within these essays is diverse and easily adaptable to the special needs of the educator looking for exciting and innovative ways to enhance student learning as well as teacher efficacy. The two chapters I found to be potentially helpful and exciting for my own future classroom include the section on promoting engagement and the one on providing access. The introduction to the first section explains that "To learn means to construct meaning rather than memorize facts. Student-instructor, student-student, and studentcontent interactions, facilitated by the use of technology, drive the effort" (Novak, 2012 , p. 2). Critical thinking skills are necessary for our students to become successful, responsible, and productive members of society. Long gone are the days when students could memorize facts and do well outside of school. Given the incredible speed of advances in technology, students must be able to learn and adapt. The students of today have also grown up in the technology age: At no time have they been without the entertainment and easy access to information provided by technology. Specific tools mentioned in the book include: using E-Rewards relating to the material being learned in class to gift students for doing well (CaseyDoecke, 2012, p. 8); having students research YouTube videos relating to classroom concepts for validity and accuracy (Owens, 2012, p. 9); providing an online forum 
for debating specific topics (Dixson, 2012, p. 12); online tools for creating visual maps of concepts; supplementing classroom lectures using podcasts (Fernandez \& Urtel, 2012, p. 37); and taking virtual field trips to enhance classroom content. These are just a few of the techniques discussed in the book. Such a plethora of technological teaching tools to enhance classroom activities can be overwhelming for the individual educator trying to decide which tools would best suit his or her needs. I found myself thinking about using so many tips provided by the essays that I became a little flustered and started to worry that I was trying to do too much. The book addresses this problem as well, by providing a chapter that "offers ideas and suggestions about how to be sure we are using technology in ways that maximize opportunities to learn but minimize extra work for students and faculty" (Dixson, 2012, p. 87). We must be careful to find a balance between the amount of technology we use in the classroom and the length of time involved in creating and implementing such programs. Educators need to be conscientious in choosing technology that enhances, rather than detracts from, the learning environment and the efficient use of class time.

Quick Hits for Teaching with Technology is a wonderful resource for educators of all academic levels and disciplines. The tips provided in these essays are tried-and-true methods for incorporating technology into today's classroom. There are so many tools available to educators today that can make the use of technology both easy and relevant for everyone involved in the educational process. I am going to end this review here, so that I can do more research on creating online debating forums, or maybe look into creating wikis; or maybe I will just go and take a virtual field trip for fun.

\section{References}

Casey-Doecke, J. (2012). Using Erewards to promote engagement and re-engagement in the online classroom. In R. K. Morgan, \& K. T. Olivares, (Eds.) Quick hits for teaching with technology: Successful strategies by award-winning teachers, (p. 8). Bloomington: Indiana University Press.

Dixson, M. D. (2012). Using teambased learning to engage students in online courses. In R. K. Morgan \& K. T. Olivares (Eds.), Quick hits for teaching with technology: Successful strategies by award-winning teachers, (pp. 12-13). Bloomington: Indiana University Press.

Morgan, R. K., \& Olivares, K. F., (Eds.). (2012). Quick hits for teaching with technology: Successful strategies by award-winning teachers. Bloomington: Indiana University Press.
Novak, G. (2012). Technology transforming learning. In R. K. Morgan \& K. T. Olivares, (Eds.), Quick hits for teaching with technology: Successful strategies by award-winning teachers (pp. 1-3). Bloomington: Indiana University Press.

Owens, J. K. (2012). YouTube reviews. In R. K. Morgan \& K. T. Olivares (Eds.), Quick hits for teaching with technology: Successful strategies by award-winning teachers (pp. 9-10). Bloomington: Indiana University Press.

Urtel, M., \& Fernandez, E. (2012). To podcast or not to podcast. In R. K. Morgan \& K. T. Olivares (Eds.), Quick hits for teaching with technology: Successful strategies by awardwinning teachers (pp. 37-38). Bloomington: Indiana Universtiy Press. 
Stephanie Healy is a recent graduate of Park University. She graduated summa cum laude with both a Bachelor of Arts in English Literature and a Bachelor of Science in Secondary Education. Stephanie is a member of Sigma Tau Delta and has recently been hired to teach English at the same high school she graduated from 20 years ago. Her experiences include working as a detention facility officer and as an instructional assistant in special education which led to her returning to school to become a certified teacher.

InSight: A J ournal of Scholarly Teaching 